\title{
Fears over Europe's GM crop plan
}

\section{A proposal to let nations opt out of growing European-approved GM varieties is under fire from all sides.}

After a decade in which just a single genetically modified (GM) crop was approved for commercial planting in the European Union (EU), the European Commission has tried to break the logjam. But its new proposal, which would allow individual member states to choose whether or not to grow an approved GM crop within their borders, is likely to create further uncertainty within the agricultural biotechnology industry. The plan has drawn fire from all sides of the intense debate over GM crops, with industry officials, farmers and anti-GM campaigners all condemning the move.

The EU currently takes advice from the European Food Safety Authority (EFSA), an independent body based in Parma, Italy, which conducts a risk assessment of each GM organism. The Council of Ministers then makes a decision on the crop that applies to farmers and agribusinesses throughout Europe. But the council's voting system means that opposition by just a few of the 27 member states can block the introduction of a crop, in which case the

European Commission makes a final decision. So far, only a potato with modified starch content - Amflora, developed for industrial rather than food use by German chemical company BASF, based in Ludwigshafen am Rhein - has been approved for cultivation in the EU, and 16 other crops are still awaiting final approval.

\section{The very real danger is}

that it risks discouraging

technology companies

investing in Europe."
The new measure, announced on 13 July, would allow member states, or even regions within countries, to restrict GM crops, regardless of whether the EFSA has determined they pose no risk to human health or the environment and whether they have been approved by the European Commission. The commission says that, in principle, the new arrangement should make it easier to secure EU-wide approval for crops.

Several companies said that although they welcomed the commission's efforts to unblock the approval process for GM crops, the plan undermines the science-based authorization process and the principles of the single market. The proposal would also allow national governments to modify the existing rule allowing products to be labelled as GM-free if they contain no more than $0.9 \%$ of GM ingredients. This would lead to a patchwork of rules across the EU, industry experts say, complicating the development of their products. "Our concern is that the proposal potentially adds more complexity and unpredictability into the process, and we doubt whether this will speed up the approvals process," says Mark Titterington, head of government and public affairs for Europe at Swiss agricultural company Syngenta. "A better and more predictable approval process, and the extent of demand from farmers for the technology, will obviously have an influence on whether we undertake GM research in Europe in the future."

Some farmers have also criticized the proposal, fearing that it will drive investment in agrobiotech away from Europe and make their industry less competitive. "This decision sends a clear signal to the rest of the world that the EU lacks interest in innovation and new technologies for a competitive agriculture industry and that it does not use evidence and science in its decision-making," the UK National Farmers

\section{US charges scientist with economic espionage}

Could publishing a scientific article constitute an act of economic espionage? That question lies at the heart of charges against a Massachusetts-based scientist accused of passing US trade secrets to China.

Ke-xue Huang, a Canadian citizen and permanent US resident, was arrested on 13 July, and has been charged under a law designed to protect intellectual property held by US companies. At a bail hearing last week in Massachusetts, the US government claimed that the scientist provided secrets belonging to Dow AgroSciences, based in Indianapolis, Indiana, to the Hunan Normal University in Changsha, China. If convicted of passing the secrets, said to be worth some $\$ 100$ million, Huang could face up to 15 years in prison for each of 12 counts of economic espionage.
The US Congress passed the Economic Espionage Act in 1996 to counter an apparent rise in foreign spies trading in commercial, rather than military, secrets. Six other cases have been prosecuted under the law, but Huang's could set a precedent for the law to be applied to industry scientists and academic researchers publishing in the open literature. This isn't the first time a scientist has faced prison time for sharing research with China; a physicist at the University of Tennessee, Knoxville, was last year sentenced to four years in prison for violating export control laws. He had provided technical data to scientists in China and worked on sensitive technologies with foreign graduate students (Nature 461, 1185; 2009).

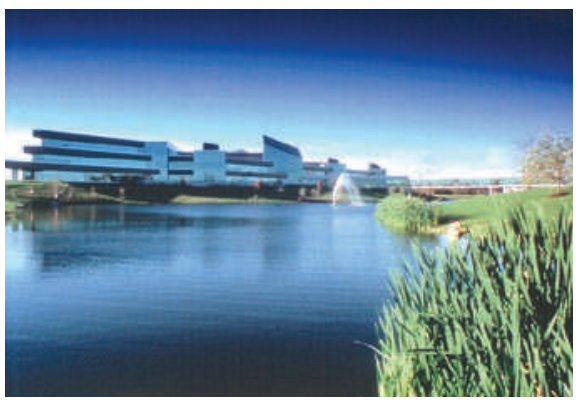

Secrets are alleged to have been stolen from Dow AgroSciences.
"It is interesting that there are - or seem to be - more cases of research triggering some government reaction, whether this is due to export control or other issues," says Thomas Zurbuchen, a space scientist at the University of Michigan in Ann Arbor who has been involved in efforts to reform export control restrictions on universities.

Huang's problems stem from research related to a review article (K. Huang et al. Appl. Microbiol. Biotechnol. 82, 13-23; 2009). Co-authored with scientists at Hunan Normal University and James Zahn, a researcher at Coskata, a biofuel company in Warrenville, Illinois, the paper describes work on a new class of insecticides that Dow has been making and marketing. The government alleges that the article contains confidential information - and that publishing it constituted theft of a trade secret, says James Duggan, Huang's lawyer. At the hearing, however, prosecutors indicated that the article is not the sole basis for the charges, which also involve e-mail communications relating to the research.

Huang worked for Dow from 


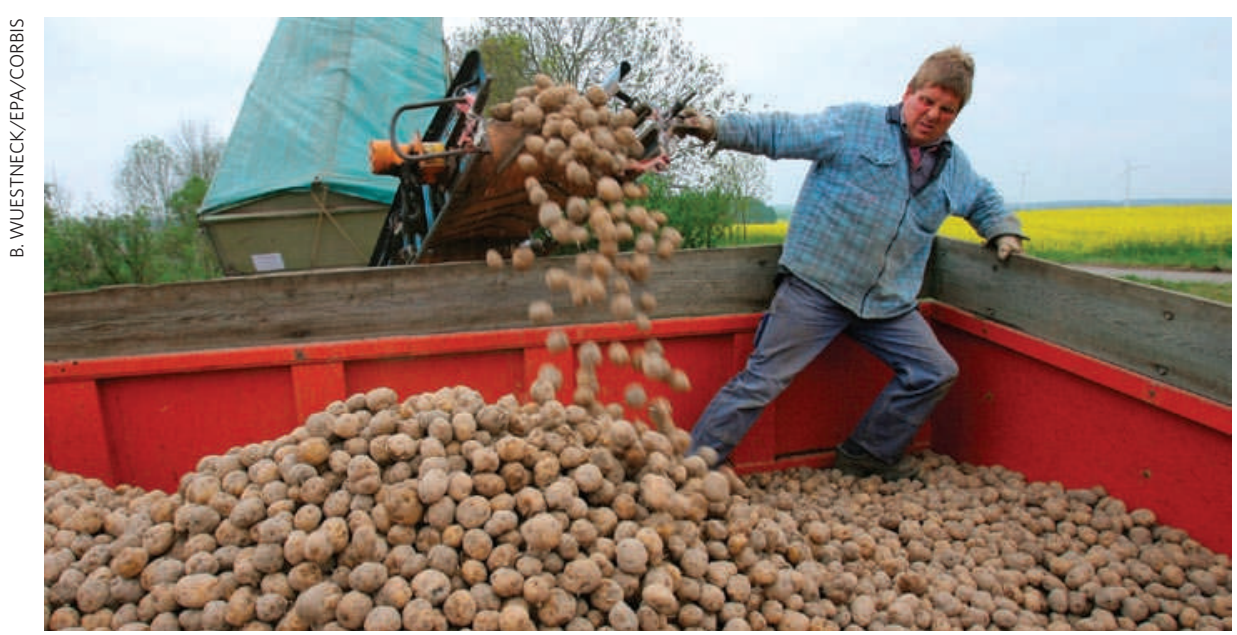

Amflora potatoes are the only genetically modified crop to be approved in Europe in the past decade.

Union's chief science and regulatory affairs adviser, Helen Ferrier, said in a statement. "The very real danger is that it risks discouraging technology companies investing in Europe."

Meanwhile, environmental groups such as Friends of the Earth and Greenpeace are concerned that devolving decision-making on GM crops will make it more difficult to block their development.

Yet not everyone sees the commission's proposal as a blow for science-based decisionmaking. "It's impossible to interpret science for the purpose of policy-making without making value judgements," says Andy Stirling, science director of the Science and Technology Policy Research unit at the University of Sussex, UK. As "agricultural systems, environments and economies all vary", he says, it is reasonable for member states to adapt scientific guidance according to their own circumstances.

The European Parliament and Council of Ministers are expected to discuss the proposals, with a view to legal implementation, this autumn.

Andrea Chipman

See Editorial, page 531 and www.nature.com/food
2003 to 2008 , but by the time of his arrest had moved to Qteros, a company based in Marlborough, Massachusetts, that works on biofuels.

Originally from China, Huang had studied biology at China's Jilin Agricultural University, and earned a PhD in Japan. After a two-year postdoctoral stint in the mid-1990s at Texas A\&M University in College Station, where he worked on sequencing biosynthetic genes for vitamin $B_{12}$ production, he went to Rice University in Houston, Texas. His postdoctoral adviser there, George Bennett, says he "couldn't imagine" Huang intentionally doing something illegal. Dow has declined to comment on any specifics of the case.

Todd Sullivan, an attorney in Raleigh, North Carolina, who specializes in trade-secret laws, compares economic espionage prosecutions to "unicorn sightings" because the government so rarely pursues them. The government has, in fact, successfully tried only one of the other six economic espionage cases. In another case, last year, a jury acquitted two Chinese-born engineers who had been charged with stealing secrets from a Californian semiconductor company and passing them on to China.

Huang's case resembles the others in that all but one involved China and Chinese scientists. The challenge for the US government will be proving that he provided intellectual property to benefit a foreign government, or an entity controlled by a foreign government. June Teufel Dreyer, a political scientist at the University of Miami in Florida who follows Chinese espionage cases, says it will be "devilishly difficult" for US prosecutors to prove that a university is controlled by the Chinese government.

But the US Department of Justice is clearly determined to try. The government is fighting attempts to release Huang on bail, and has asked that, even if he is released, his use of the Internet and e-mail be restricted.

In the meantime, Duggan says that he does not concede that his client stole trade secrets, or even that he violated any employment agreement with Dow. He says that Huang was motivated not by espionage, but by his desire to improve insecticides and benefit crop production. "His motives were excellent motives,"

Duggan insists. "Dow's motives are to protect its profits."

Sharon Weinberger 